\title{
The Effect of Microwave Cooking on Nutrient Value of Fresh Vegetables
}

\author{
M. A. Rashid", Md. Iqbal Hussain, Atiqur Rahman, Mst Khodeza Khatun, M. A. Sattar \\ Department of Applied Chemistry and Chemical Technology, Islamic University, Kushtia, Bangladesh
}

Email address:

marashid222@gmail.com (M. A. Rashid)

"Corresponding author

\section{To cite this article:}

M. A. Rashid, Md. Iqbal Hussain, Atiqur Rahman, Mst Khodeza Khatun, M. A. Sattar. The Effect of Microwave Cooking on Nutrient Value of Fresh Vegetables. International Journal of Nutrition and Food Sciences. Vol. 5, No. 4, 2016, pp. 273-277.

doi: $10.11648 /$ j.ijnfs.20160504.16

Received: May 17, 2016; Accepted: June 15, 2016; Published: June 30, 2016

\begin{abstract}
Microwave cooking has gained considerable importance as an energy-saving, convenient and time-saving cooking method. This study was performed to compare the effects of microwave cooking and conventional cooking method on proximate nutrient and health promoting contents of fresh Cowpea (Vigna unguiculata) and Zhinggye (Luffa acutangula) grown in Bangladesh. The moisture and ash content in raw Cowpea were $92.19 \%$ and $0.48 \%$, respectively, for Zhinggye they were $95.87 \%$ and $0.25 \%$, respectively. After conventional cooking moisture and ash content were $93.37 \%$ and $0.33 \%$, respectively, for Cowpea whereas $95.75 \%$ and $0.23 \%$, respectively, for Zhinggye. On the other hand, after microwave cooking these values were $92.32 \%$ and $0.48 \%$, respectively, for Cowpea and $95.53 \%$ and $0.25 \%$, respectively, for Zhinggye. Total crude protein, fat and carbohydrate were significantly modified by both cooking methods. In both cases, microwave cooking decreased the vitamin-C content to some extent but the conventional cooking completely destroyed the vitamin- $\mathrm{C}$ contents.
\end{abstract}

Keywords: Microwave Cooking, Nutritional Value, Fresh Vegetables, Vigna Unguiculata, Luffa Acutangula

\section{Introduction}

Cooking as a domestic processing method has a great impact on food nutrients. In general, vegetables are prepared at home on the basis of convenience and taste preference rather than retention of nutrient and health-promoting compounds [1]. It is known that cooking induces significant changes in chemical composition, affecting the bioavailability and content of chemopreventive compounds in vegetables. Cooking methods were shown to affect the contents of nutrient and health-promoting compounds such as vitamin $\mathrm{C}$, carotenoids, polyphenols, and glucosinolates [25]. The cooking procedures such as boiling and microwaving used in these studies were based on the dietary habit in Bangladesh. The microwave cooking process presents controversial results in the literature due to the different conditions that are employed (time, power, and added water).

Cowpeas (Vigna unguiculata L.) are one of the most important food legume crops in the semi-arid tropics covering Asia, Africa, Southern Europe and Central and
South America. A drought-tolerant and warm-weather crop, cowpeas are well-adapted to the drier regions of the tropics, where other food legumes do not perform well. It also has the useful ability to fix atmospheric nitrogen through its root nodules, and it grows well in poor soils with more than $85 \%$ sand and with less than $0.2 \%$ organic matter and low levels of phosphorus [6]. Cowpea seed and its protein isolate are useful for remedying diet-induced hypercholesterolemia and steatosis, even in diets containing high levels of saturated fatty acids and cholesterol. The effectiveness of the isolate is lower than that of the whole seed, probably because several components, such as plant sterols, saponins, resistant starches, and soluble fiber present in the intact seed can act synergistically [7].

Zhinggye (Luffa acutangula L.) is an important warm season cucurbitaceous vegetable crop grown in different parts of Bangladesh, India and in the tropical countries of Asia and Africa. Its immature fruits are cooked as vegetable and also used in the preparation of chutneys and curries. Being a warm season crop, it has the ability to tolerate hotter conditions, which makes it suitable for widespread 
cultivation throughout the tropics [8]. A natural jaundice remedy, the fruits of Luffa acutangula are grown, harvested before maturity and is very popular in Asia. Ridge gourd as whole, seeds and dried crusts are all used for medicinal purposes [9].

This study tried to reveal a suitable cooking method which will help to provide us more nutrient rich cooked food by comprising conventional cooking and microwave cooking method so that it is possible to overcome the nutrient lacking problems.

\section{Materials and Methods}

\subsection{Preparation of Sample}

Fresh vegetables Cowpea (Vigna unguiculata L.) and Zhinggye (Luffa acutangula L.) were collected from local market (Sheikh Para, Kushtia, Bangladesh). Samples were washed properly and cut into small pieces from the edible part of the green vegetables.

\subsection{Conventional Cooking}

Among various methods of conventional cooking, boiling method was applied in the study for the cooking of the selected sample. In this case, the sample to be cooked was just immersed in water at $100^{\circ} \mathrm{C}$ and the water was maintained at that temperature till the sample was tendered. In this cooking method, each sample was cooked for 10 minutes.

\subsection{Microwave Cooking}

A weighed, chopped sample was placed in a 250-ml beaker. The sample in the microwave oven was cooked until it is tender (about $45 \mathrm{~s}$ in a $700 \mathrm{~W}$ oven). Remove the sample from the oven and the nutrition values were estimated.

\subsection{Determination of Moisture Content}

Moisture was determined by oven drying method. A clean crucible was dried to a constant weight in air oven at $110^{\circ} \mathrm{C}$, cooled in a desiccator and weighed (W1). Two grams of finely ground sample was accurately weighed into the previously labeled crucible and reweighed (W2). The crucible containing the sample was dried in an oven to constant weight (W3). The percentage moisture content was calculated as follows:

$$
\% \text { Moisture content }=\frac{(\mathrm{W} 2-\mathrm{W} 3) \times 100}{\mathrm{~W} 2-\mathrm{W} 1}
$$

\subsection{Determination of Ash Content}

For the determination of ash, a clean porcelain crucible was dried in an oven at $100^{\circ} \mathrm{C}$ for $10 \mathrm{~min}$, cooled in a desiccator and weighed (W1). Two grams of the finely ground sample was placed into a previously weighed porcelain crucible and reweighed (W2), it was first ignited and then transferred into a furnace which was set at $550^{\circ} \mathrm{C}$. The sample was left in the furnace for eight hours to ensure proper ashing. The crucible containing the ash was then removed; cooled in a desiccator and weighed (W3). The percentage ash content was calculated as follows:

$$
\% \text { Ash content }=\frac{(\mathrm{W} 3-\mathrm{W} 1) \times 100}{\mathrm{~W} 2-\mathrm{W} 1}
$$

\subsection{Determination of Protein Content}

Protein in the sample was determined by Kjeldahl method [10]. $2 \mathrm{~g}$ of dried samples was taken in digestion flask. Add 10-15 ml of concentrated $\mathrm{H}_{2} \mathrm{SO}_{4}$ and $8 \mathrm{~g}$ of digestion mixture i.e. $\mathrm{K}_{2} \mathrm{SO}_{4}: \mathrm{CuSO}_{4}(8: 1)$. The flask was swirled in order to mix the contents thoroughly then placed on heater to start digestion till the mixture become clear (blue green in color). It needs $2 \mathrm{hrs}$ to complete. The digest was cooled and transferred to $100 \mathrm{ml}$ volumetric flask and volume was made up to mark by the addition of distilled water. Distillation of the digest was performed in Markam Still Distillation Apparatus [11]. Ten milliliters of digest was introduced in the distillation tube then $10 \mathrm{ml}$ of $0.5 \mathrm{~N}$ $\mathrm{NaOH}$ was gradually added through the same way. Distillation was continued for at least $10 \mathrm{~min}$ and $\mathrm{NH}_{3}$ produced was collected as $\mathrm{NH}_{4} \mathrm{OH}$ in a conical flask containing $20 \mathrm{ml}$ of $4 \%$ boric acid solution with few drops of modified methyl red indicator. During distillation yellowish color appears due to $\mathrm{NH}_{4} \mathrm{OH}$. The distillate was then titrated against standard $0.1 \mathrm{~N} \mathrm{HCl}$ solution till the appearance of pink color. A blank was also run through all steps as above. Percent crude protein content of the sample was calculated by using the following formula:

$$
\% \text { Protein }=6.25 \mathrm{X}=\frac{(\text { Sample Titration }- \text { Blank Titration }) \text { X Strength of HCl X 0.014 X Volume of digest Sample X } 100}{\text { Wt. of the sample X Volume taken for Distillation }}
$$

\subsection{Determination of Fat Content}

The fat content was determined by ether extract method using Soxhlet apparatus [12]. Since all the fat materials e.g. fats, phospholipids, sterols, fatty acids, carotenoids, pigments, chlorophyll etc. are extracted together therefore, the results are frequently referred to as crude fat. Approximately $1 \mathrm{~g}$ of moisture free sample was wrapped in filter paper, placed in fat free thimble and then introduced in the extraction tube. Weighed, cleaned and dried the receiving beaker was filled with petroleum ether and fitted into the apparatus. Turned on water and heater to start extraction. After 4-6 siphoning allow ether to evaporate and disconnect beaker before last siphoning. Transferred extract into clean glass dish with ether washing and evaporated ether on water bath. Then placed the dish in an oven at $105^{\circ} \mathrm{C}$ for $2 \mathrm{hrs}$ and cooled it in a desiccator. The percent crude fat was determined by using the following formula: 


$$
\% \text { Fat content }=\frac{\text { Wt. of Ether Extract X } 100}{\text { Wt. of Sample }}
$$

\subsection{Determination of Carbohydrate Content}

The total carbohydrate was determined by difference. The sum of the percentage moisture, ash, crude protein and crude fat was subtracted from 100 [13].

$\%$ Carbohydrate $=100$ - (moisture content + ash content + protein content + fat content $) \%$

\subsection{Determination of Vitamin C Content}

Vitamin $\mathrm{C}$ content was determined according to the Association of Official Analytical Chemists (AOAC) Official Method 985.33 (2, 6-dichloroindophenol titrimetric method) [14]. Vitamin C content is expressed as $\mathrm{mg} / 100 \mathrm{~g}$ fresh weight.

\subsection{Statistical Analysis}

The nutrient contents from these samples were estimated in triplicate, and mean values were calculated. A Student's ttest was computed for the statistical significance of the results.

\section{Result and Discussion}

Food preparation is an important step in meeting the nutritional needs of the family. Food has to be pleasing in appearance and taste in order to be consumed. Cooking as a conventional processing method has a great impact on food nutrients. Most foods are mainly consumed after being cooked and cooking considerably affects their healthpromoting compounds, minerals and vitamins. In this study tried to picture the changes brought by cooking (microwave and conventional method) in the nutrient content of two fresh vegetables collected from local market named as Cowpea and Zhinggye.

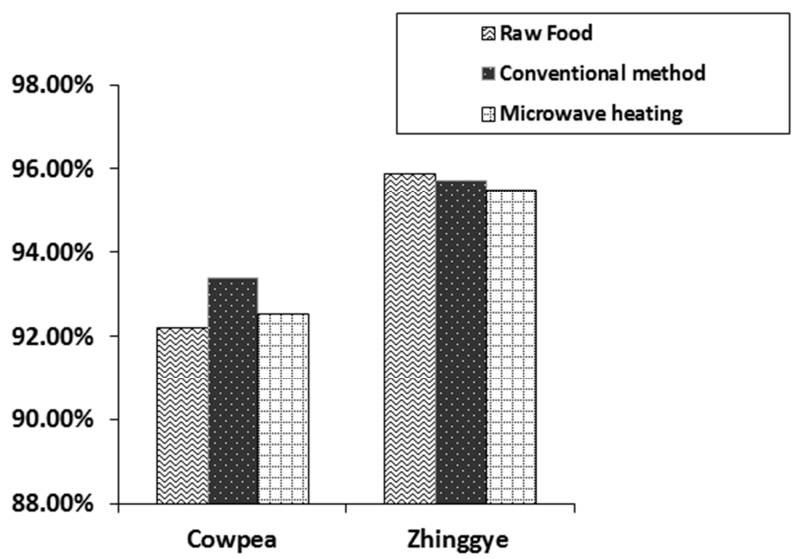

Figure 1. The moisture congtent in Cowpea and Zhinggye cooked by different methods.

Previous studied showed that raw samples of Cowpea contained $87 \%$ moisture, $0.2 \%$ fat, $3 \%$ protein, $9 \%$ carbohydrate and Zhinggye contained $93 \%$ moisture, $0.6 \%$ fat, $1.8 \%$ protein, $4.3 \%$ carbohydrate. [15] In this study, the moisture content in raw Cowpea and Zhinggye were $92.19 \%$ and $95.87 \%$, respectively. After conventional cooking moisture content in Cowpea and Zhinggye were $93.37 \%$ and $95.75 \%$, respectively, whereas after microwaving, 92.32\% and $95.53 \%$, respectively, were found for Cowpea and Zhinggye (Figure 1). Ash content in raw Cowpea was $0.48 \%$, but after conventional and microwave cooking it was found $0.33 \%$ and $0.48 \%$, respectively. On the other hand, ash content in raw Zhinggye was $0.25 \%$, but after conventional and microwave cooking it was found $0.23 \%$ and $0.25 \%$, respectively (Figure 2).

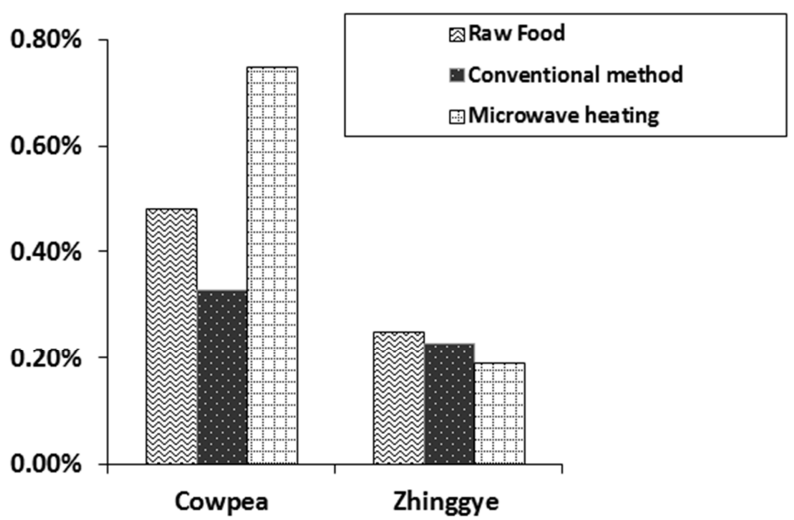

Figure 2. The ash congtent in Cowpea and Zhinggye cooked by different methods.

Total crude protein of raw Cowpea was $2.50 \%$. After conventional and microwave cooking it was found $2.00 \%$ and $2.50 \%$, respectively. On the other hand, crude protein content in raw Zhinggye was $0.94 \%$, but after conventional and microwave cooking it was found $0.88 \%$ and $0.94 \%$, respectively (Figure 3). As showed in Figure 4, crude fat in raw Cowpea was $0.048 \%$. After conventional and microwave cooking it was found $0.027 \%$ and $0.019 \%$, respectively. On the other hand, crude fat content in raw Zhinggye was $0.52 \%$, but after conventional and microwave cooking it was found $0.44 \%$ and $0.28 \%$, respectively.

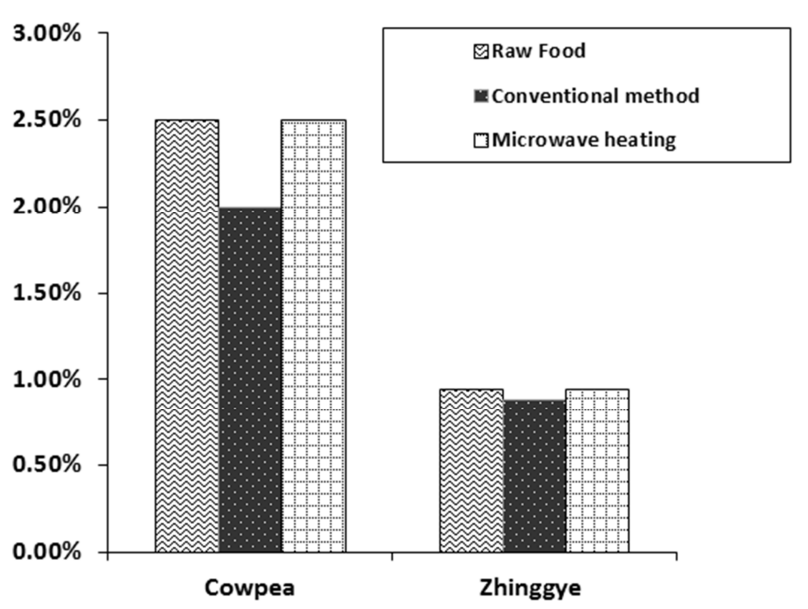

Figure 3. The portein congtent in Cowpea and Zhinggye cooked by different methods. 


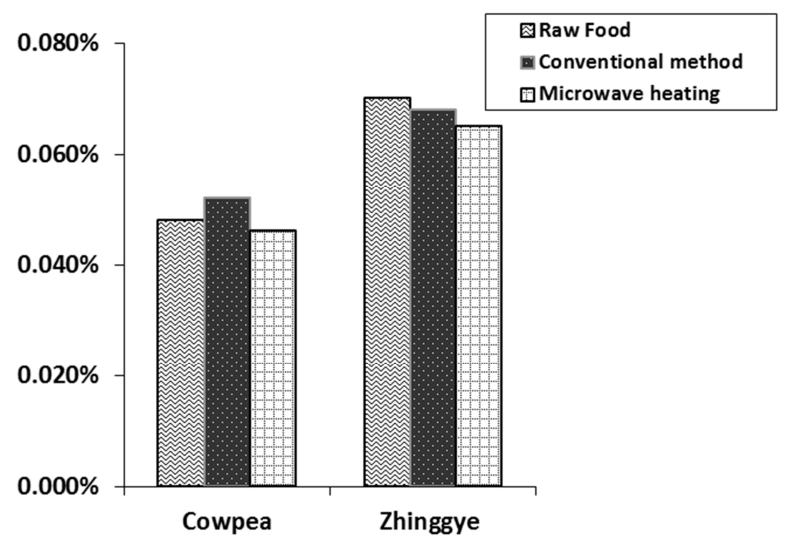

Figure 4. The fat content in Cowpea and Zhinggye cooked by different methods.

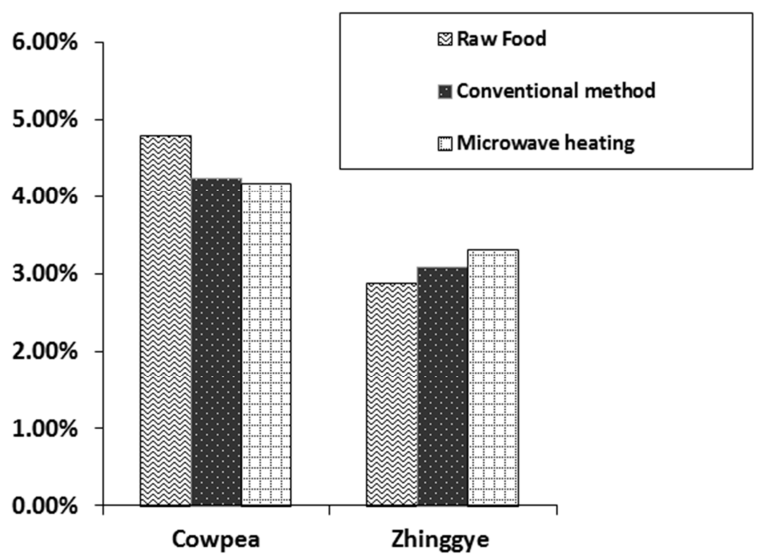

Figure 5. The carbohydrate content in Cowpea and Zhinggye cooked by different methods.

The cabohydrate content in raw Cowpea and Zhinggye was $4.78 \%$ and $2.42 \%$, respectively. $4.27 \%$ carbohydrate was found in Cowpa after conventional cooking while $4.68 \%$ carbohydrate was found after microwave cooking. On the other hand, 2.7\% carbohydrate was found in Zhinggye after conventional cooking while $3 \%$ carbohydrate was found after microwave cooking (Figure 5).

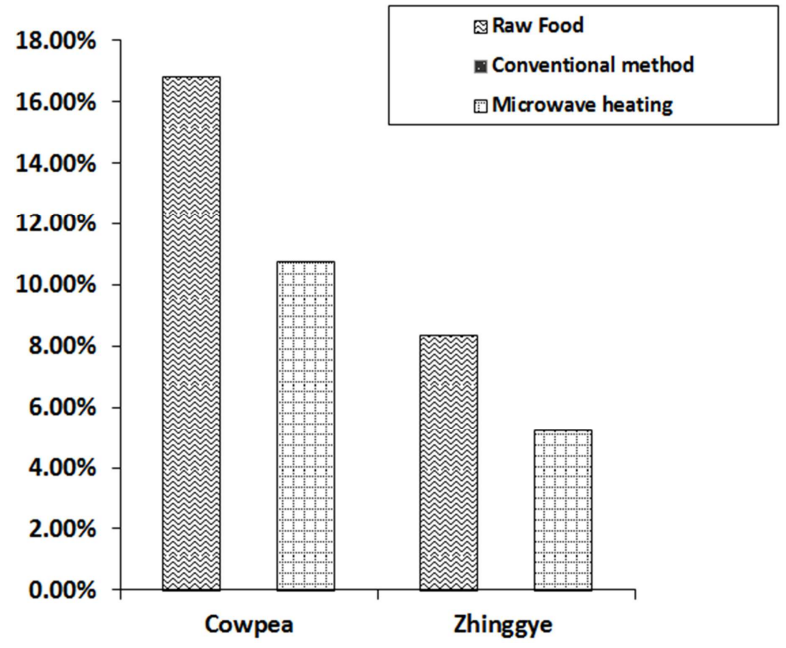

Figure 6. The Vitamin-C content in Cowpea and Zhinggye cooked by different methods.
Vitamin $\mathrm{C}$ is one of the most important nutrients in many other horticultural crops and has many biological functions in the human body [16]. The concentration of ascorbic acid (the predominant form of vitamin C) in fresh vegetables generally decreased after cooking [17]. Both cooking treatments caused a dramatic loss of vitamin C. $16.82 \%$ and $8.35 \%$ of vitamin C was observed in raw Cowpea and Zhinggye, respectively. After microwaving $10.78 \%$ and $5.24 \%$ of vitamin $C$ was observed in Cowpea and Zhinggye, respectively, while conventional cooking completely destroyed the vitamin-C in both vegetables (Figure 6).

\section{Conclusion}

Cowpea (Vigna unguiculata) and Zhinggye (Luffa acutangula) have been cooked by microwave and conventional methods and compared these methods for protein, fat, carbohydrate, moisture, ash and vitamin $\mathrm{C}$ contents. Microwave heating has a number of quantitative and qualitative advantages over conventional heating techniques that make its adoption a serious proposition. One main advantage is the place where the heat is generated, namely the product itself. Because of this, the effect of small heat conductivities or heat transfer coefficients does not play such an important role. Therefore, larger pieces can be heated in a shorter time and with a more even temperature distribution. These advantages often yield an increased production. Bangladesh is an under developing country and many people of this country are suffering from nutritional problem. For this reason people should choice the best method of cooking by which nutrient content are present in high amount. Results of this study suggested that microwave cooking method is better than other methods because microwave cooked food contains high amount of nutrients.

\section{References}

[1] Masrizal, M. A., Giraud, D. W. and Driskell, J. A. 1997. Retention of vitamin C, iron, and beta-carotene in vegetables prepared using different cooking methods. J. Food Qual. 20 (5), 403-418.

[2] Cieslik, E., Leszczynska, T., Filipiak-Florkiewicz, A., Sikora E. and Pisulewski P. M. 2007. Effects of some technological processes on glucosinolate contents in cruciferous vegetables. Food Chem. 105 (3), 976-981.

[3] Lin, C. H. and Chang, C. Y. 2005. Textural change and antioxidant properties of broccoli under different cooking treatments, Food Chem. 90 (1-2), 9-15.

[4] Sikora, E., Cieslik, E., Leszczynska, T., Filipiak-Florkiewicz, A. and Pisulewski, P. M. 2008. The antioxidant activity of selected cruciferous vegetables subjected to aquathermal processing. Food Chem. 107 (1), 55-59.

[5] Vallejo, F., Tomas-Barberan, F. A. and Garcia-Viguera, C. 2002. Glucosinolates and vitamin $C$ content in edible parts of broccoli florets after domestic cooking. Eur. Food Res. Technol. 215 (4), 310-316. 
[6] Singh, B. 2003. Improving the production and utilization of cowpea as food and fodder, Field Crops Research. 84, 169150.

[7] Frota, K. M. G., Mendonc, S., Saldiva, A. P. H. N., Cruz, R. J. and Areas, J. A. G. 2008. Cholesterol-Lowering Properties of Whole Cowpea Seed and Its Protein Isolate in Hamsters, Journal of Food Science. 73 (9). 235-240.

[8] Choudhary, B. R., Kumar, S., Sharma, S. K., 2014. Evaluation and correlation for growth: yield and quality traits of ridge gourd (Luffa acutangula) under arid conditions. Indian J. Agric. Sci. 84, 498-502.

[9] Pullaiah T. 2006. Encyclopedia of world medicinal plants, Daya books, Vol 2, 1271-1274.

[10] Williams, K. A. 1966. Oils, Fats and Fatty foods, J \& A. Churchil Ltd. London. 4, 136.

[11] Khalil, I. A. and Manan, F. 1990 Text book of Chemistry I. Bio. Analytical Chemistry $2^{\text {nd }}$ Edn. Taj Kutab Khana, Peshawar.
[12] AOAC, Official Methods of Analysis of AOAC International. 1984. Gaithersburg (MD) A. O. A. C. International.

[13] Muller, H. G. and Tobin, G. 1980. Nutrition and Food Processing, Croom Helm, London.

[14] AOAC (Association of Official Analytical Chemists), Official Method 985.33. 1990. Vitamin C (Reduced Ascorbic Acid) in Ready-to-feed Milk-based Infant Formula 2, 6Dichloroindophenol Titrimetric Method. 1108-1109.

[15] "Deshio Khadda Drobber Poshtiman (Bangla)", 1980. Institute of Nutrition and Food Science, Dhaka University, Dhaka. 12.

[16] Lee, S. K. and Kader, A. A. 2000. Preharvest and postharvest factors influencing vitamin $\mathrm{C}$ content of horticultural crops, Postharvest Biol. Technol. 20 (3), 207-220.

[17] Serrano, M., Martinez-Romero, D., Guillen, F., Castillo, S. and Valero, D. 2006. Maintenance of broccoli quality and functional properties during cold storage as affected by modified atmosphere packaging, Postharvest Biol. Technol. 39 (1), 61-68. 